\title{
PARTICIPAÇÃO POPULAR NO PROCESSO DE ELABORAÇÃO DO ORÇAMENTO PARTICIPATIVO. A EXPERIÊNCIA DE PORTO ALEGRE
}

\section{POPULAR PARTICIPATION IN THE PARTICIPATORY BUDGET'S PROCESS. PORTO ALEGRE'S EXPERIENCE}

\author{
André Alves Portella ${ }^{1}$ \\ Maria Helena Ochi Flexor ${ }^{2}$ \\ Rubens Mario Ribeiro Pacheco ${ }^{3}$
}

\section{RESUMO}

Este artigo tem por objetivo analisar a participação da população do município de Porto Alegre no processo de elaboração do Orçamento Participativo, por meio do exame das disposições legais disponíveis e de forma a identificar as dificuldades de implementação apontadas por alguns agentes do processo, bem como da doutrina especializada. A pesquisa parte da leitura de documentos disponíveis em bases de dados eletrônicos e relatórios oficiais, bem como da análise da bibliografia existente sobre o tema. Observou-se ao longo do estudo que ainda é escassa a utilização de instrumentos que viabilizem a participação popular na elaboração da estrutura de financiamento público, em especial no que se refere à elaboração do Orçamento Público municipal, em que pese a sua relevância para a qualidade da democracia.

Palavras-chave: Orçamento participativo. Participação popular. Democracia. Município. Municipalidade.

\begin{abstract}
This article aims to analyze the participation of Porto Alegre city population in the process of elaboration of the participatory budget, through the examination of the available legal provisions and in order to identify the difficulties of implementation indicated by some agents of the process, as well as in specialized doctrine. The research is part of reading documents available in electronic databases and official reports, also the analysis of bibliography on the subject. It was observed throughout the study that is still scarce the use of instruments that enable the popular participation in the elaboration of the public financing structure, especially about to elaboration of the municipal public budget, which considers its relevance to the quality of democracy.

\footnotetext{
${ }^{1}$ Pós-doutor Doutor em Sociologia, Filosofia e Antropologia Política, pela Université de Nanterre, Paris X, Doutor em Direito Financeiro e Tributário, pela Universidad Complutense, de Madrid. Professor da Faculdade de Direito da UFBA, UCSal e UNIFACS. Universidade Federal da Bahia; Universidade Católica de Salvador - Brasil. ORCID: https://orcid.org/0000-0003-0196-9633 Lattes: http://lattes.cnpq.br/1782631349656661 E-mail: aaportella@hotmail.com

${ }^{2}$ Doutora pela Universidade São Paulo - USP, Professora Emérita da Universidade Federal da Bahia. USP, UFBA

- Brasil. Lattes: http://lattes.cnpq.br/4600166750512322 E-mail: aaportella@ hotmail.com

${ }^{3}$ Mestrando em Planejamento Territorial e Desenvolvimento Social, pela UCSal. Professor da UNEB. UCSal, UNEB - Brasil. Lattes: http://lattes.cnpq.br/9123109832662325 E-mail: aaportella@ hotmail.com
} 
Keywords: Participatory Budgeting. Popular Participation. Democracy. Municipality.

\section{INTRODUÇÃO}

Na perspectiva do financiamento público, o exercício da democracia no Brasil tem como principal instrumento o Orçamento Participativo. Embora a sua efetiva utilização encontre-se ainda muito aquém do desejável em termos de participação popular, o mesmo tem um poder simbólico importante, enquanto instrumento viabilizador da democracia no âmbito da tomada de decisões sobre a alocação dos recursos públicos.

O município de Porto Alegre tornou-se uma referência internacional em termos de aplicação das técnicas inerentes ao Orçamento Participativo, e um laboratório que possibilita tanto a observação de tais técnicas, como também de verificação dos seus impactos políticos e sociais. A experiência porto-alegrense tem se dado desde o final da década de 1980, aplicada a um espaço que conta com população estimada de 1.484 .941 e densidade demográfica de 2.837,53 hab/km² (IBGE, 2010, 2019) .

Por meio do Orçamento Participativo, a população encontra espaço e é estimulada a debater e definir as políticas públicas que serão adotadas no município. Através dele a vontade popular se manifesta com a indicação da ordem de prioridade das obras e serviços a serem realizados. O governante, através de consultas, feitas em reuniões abertas à sociedade, acatando suas demandas prioritárias pode determinar o que incluir na Lei Orçamentária Anual (LOA) como resultado desta participação popular.

O presente estudo se propõe a analisar a forma como se dá a participação da população da cidade de Porto Alegre no processo de elaboração do Orçamento Participativo, examinando os instrumentos que viabilizam a sua elaboração, e identificando as dificuldades de implementação apontadas por alguns autores. Busca-se evidenciar desta forma o exercício da democracia por meio da participação popular, com a confrontação com os resultados em termos de efetivação de políticas públicas.

\footnotetext{
${ }^{4}$ O Estado possui uma população estimada 11.377.239 habitantes, com 37,96 hab/km² (IBGE, 2010, 2019). Disponível em: https://cidades.ibge.gov.br/brasil/rs/panorama. Acessado em 20 out. 2019.
} 
A pesquisa foi realizada através de revisão bibliográfica consistente em livros, artigos científicos, revistas e jornais de grande circulação, documentos e sites oficiais. Foram solicitados documentos ao município através de e-mails e contatos telefônicos.

O trabalho expõe inicialmente os conceitos de Estado e democracia participativa, por serem conceitos fundamentais ao enquadramento da temática tratada. Em segundo lugar, trata de examinar as características fundamentais do Município de Porto Alegre, bem como a evolução histórica do Orçamento Participativo neste território. Finalmente, são destinados alguns tópicos ao estudo do Orçamento Participativo, no que se refere à sua estrutura, à sua dinâmica, e aos aspectos inerentes à participação popular na sua elaboração.

\section{ESTADO E DEMOCRACIA PARTICIPATIVA}

Democracia é o governo do povo, para o povo, pelo povo (GOYARD-FABRE, 2003) sendo "povo" o componente fundamental, tanto do conceito, como de todo o processo de vivência e governabilidade em um regime democrático pleno. Contrario sensu, na ausência de canais que possibilitem a participação efetiva do povo nas estruturas do Estado contemporâneo leva a uma fragilização dos regimes democráticos (GOYARD-FABRE, 2003, p. 282).

A democracia pode ser do tipo direta, semidireta, ou participativa. A democracia direta é aquela cujas decisões políticas são adotadas sem que haja a intermediação política. Cada cidadão manifesta a sua vontade, e as decisões são efetivadas a partir da verificação da maioria. $\mathrm{Na}$ democracia semidireta, a população delega, através de votos em sistema eleitoral constituído, o poder de representação. Finalmente, na democracia participativa são conjugados elementos das duas formas anteriores, de modo que o povo delega poderes a representantes eleitos, mas também participa dos processos de tomada de decisões políticas e administrativas.

A democracia participativa é efetivada por meio da criação de canais de comunicação político-institucionais com a população, de forma a possibilitar que cada cidadão expresse a sua vontade política, e atue de forma ativa, valorizando-se como principal componente da governabilidade (CARRION, 2001). Perez (2009) salienta que a democracia participativa possibilita a realização do controle sobre a administração pública, por parte da sociedade, na medida em que viabiliza a participação dos cidadãos nas discussões sobre assuntos importantes para a coletividade.

A efetivação da democracia participativa exige a criação e aperfeiçoamento de instrumentos de controle e de participação no poder, com destaque para os mecanismos de 
controle social (CARRION, 2001). A Constituição Federal de 1988 (CF/88) elenca alguns instrumentos tradicionais que se encontram presentes num sistema de democracia participativa, a exemplo do plebiscito - que condiciona à consulta popular a vigência de uma norma a ser criada -, do referendo - que submete à consulta popular a confirmação de uma norma já vigente - e iniciativa popular - que possibilita a apresentação de projeto de lei por parte da sociedade - .

O sistema democrático estabelecido por meio da $\mathrm{CF} / 88$ foi resultado da implementação das técnicas de controle social em cinco dimensões distintas: "formulação", "deliberação", "monitoramento", "avaliação" e "financiamento das políticas públicas" (MORONI, 2009, p. 116).

A efetivação da democracia participativa vai muito além de formalidades previstas no plano normativo, para atuar no plano da relação entre instituições do Estado e os membros da sociedade, bem como na configuração de uma consciência política e cidadã: "sem a participação popular não há democracia, menos ainda cidadania, desenvolvimento da consciência de cidadão, consciência crítica e consciência política” (Brandão, 2005, p. 109).

No âmbito do poder local, a democracia participativa tem fomentado a legitimação de políticas com a ocupação paulatina das arenas decisórias, de forma a desencadear um aumento da iniciativa popular na gestão pública, na linha do que afirma Di Pietro:

O Estado Democrático de Direito trouxe a ideia de participação do cidadão na Administração Pública, combatendo a separação entre Estado e sociedade e pregando a adoção de uma Administração menos autoritária, menos centralista, menos hierarquizada, mais próxima do cidadão (DI PIETRO, 2000, p. 39).

Neste contexto, o Orçamento Participativo assume um lugar de destaque. Trata-se de instrumento que viabiliza o exercício da participação popular, dentro de um sistema de democracia participativa. Tal participação é realizada por meio da tomada de decisões sobre alocação dos recursos financeiros que são arrecadados a partir dos esforços de toda a sociedade, e é por isso a compreensão do seu processo extrapola as questões da técnica financeira ou orçamentária para incluir a dimensão política da participação cidadão. O estudo da experiência do município de Porto Alegre é fundamental, na medida em que se trata de um modelo pioneiro e referência internacional no tema. 


\title{
3. MUNICÍPIO DE PORTO ALEGRE/RS NO TEMPO E NO ESPAÇO
}

O processo histórico de formação do município de Porto Alegre encontra-se relacionado de forma direta ao surgimento do próprio Estado do Rio Grande do Sul, e sempre vinculado ao processo de conquista e ocupação daquela porção sul do território nacional. Na sua origem encontravam-se ali bandeirantes paulistas e tropeiros paulistas, jesuítas espanhóis dos Sete Povos com seus índios aldeados, além de portugueses. A partir de 1732 os povoadores começam a realizar a ocupação definitiva, na forma de sesmarias decorrentes de doação real (IBGE, 1959, 58). De maneira mais precisa, a evolução político-administrativa se deu nos seguintes moldes:

\begin{abstract}
A Capital do Estado do Rio Grande do Sul originou-se do povoado de Pôrto de São Francisco dos Casais, fundado em 1742, e elevado à atual categoria em 24 de julho de 1773. O município, criou-o a Ordem Régia de 26 de janeiro ou 23 de agôsto de 1803, recebendo a sua sede predicamento de vila.

O Ato Municipal $\mathrm{n}^{\circ} 7$, de 1 de dezembro de 1892, criou o distrito-sede do município de Porto Alegre, que, na "Divisão Administrativa, em 1911", aparece subdividido em 11 distritos: $1^{\circ}, 2^{\circ}$ e $3^{\circ}$, formando a Cidade, e os de Glória, Belém Novo, Pedras Brancas, Barra do Ribeiro, Mariana Pimentel, Ilhas Fronteiras, Tapes e Dores de Camaquã.

O Decreto-lei Estadual n ${ }^{\circ} 720$, de 29 de dezembro de 1944, que fixou a divisão territorial do Estado, a vigorar no quadriênio 1945-1948, manteve para Pôrto Alegre a mesma composição distrital do quinquênio anterior, com a alteração única de que as zonas do distrito-sede passaram a constituir, sob denominações idênticas e nesse próprio distrito, igual número de subdistritos. (IBGE, 1959, volume XXXIV, p. 72-73).
\end{abstract}

Em 1752, 60 casais açorianos chegaram ao território, levados pelo Governo Português para povoá-lo, como decorrência do acordo feito com a Espanha, através do Tratado de Madri, de 1750. Nessa ocasião, a região Noroeste do Estado, que corresponde ao que hoje se denomina Sete Povos das Missões, foi entregue ao governo português, em troca da Colônia de Sacramento, um presídio, nas margens do Rio da Prata (PORTO ALEGRE. Prefeitura, 2018), pertencente hoje ao Uruguai.

Em 1772, sob o comando do governador José Marcelino de Figueiredo, o povoado desenvolveu maior nível de regularidade de gestão e de organização jurídica e territorial. A sesmaria, então pertencente a Inácio Francisco, foi desapropriada e parcelas de terra foram distribuídas entre os colonos ilhéus. Ainda neste momento, foi lançada a pedra fundamental de uma igreja, que viria a se tornar a velha Catedral da Praça da Matriz. No ano seguinte, mudou- 
se o orago da igreja, que passou de São Francisco Xavier para Nossa Senhora da Madre de Deus (IBGE, 1959, p. 59).

Também de 1773 data o nome do que ainda era apenas uma freguesia, e que passou a se chamar Nossa Senhora da Madre de Deus de Pôrto Alegre. O alvará de 27 de agosto de 1808 e a Resolução Régia de 7 de outubro de 1809 elevaram a freguesia à categoria de vila, verificando-se a instalação em 11 de dezembro de 1810. Em 1812 Porto Alegre tornou-se sede da Capitania de São Pedro do Rio Grande, recém-criada, e cabeça da comarca de São Pedro do Rio Grande e Santa Catarina. Foram necessários quase 10 anos para que o Decreto de D. Pedro I, de 1822, elevasse o território à categoria de cidade, "com todos os foros e prerrogativas das outras cidades do Império" (IBGE, 1959, p. 59, 61).

Segundo o Censo do IBGE, de 2010, o município de Porto Alegre conta com uma população estimada de 1.484 .941 habitantes, distribuída numa área de $496,682 \mathrm{~km}^{2}$, o que lhe confere uma densidade demográfica de aproximadamente $2.837,53 \mathrm{hab} / \mathrm{km}^{2}$, com um PIB per capita da ordem de R $\$ 46.122,79$ (IBGE, 2010, 2019).

Com múltiplas origens étnicas, religiosas e linguísticas, Porto Alegre é hoje, com seu quase 1,5 milhão de habitantes, uma cidade cosmopolita e multicultural, numa demonstração bem sucedida de diversidade e pluralidade. (PORTO ALEGRE, Prefeitura, 2018). O seu desenvolvimento foi contínuo ao longo do tempo e a cidade manteve-se no centro dos acontecimentos culturais, políticos e sociais do país como terra de grandes escritores, intelectuais, artistas, políticos e acontecimentos que marcaram a história do Brasil. (PORTO ALEGRE, 2018).

O Índice de Desenvolvimento Humano Municipal (IDHM) Porto Alegre é 0,805, o que situa o município na categoria de Desenvolvimento Humano Muito Alto (IDHM), que vai de 0,800 a 1,0). A dimensão, que mais contribui para o IDHM do município é a renda, com índice de 0,867, seguida de longevidade, com índice de 0,857, e de educação, com índice de 0,702. No contexto da realidade nacional, Porto Alegre ocupa a $28^{\mathrm{a}}$ posição ${ }^{5}$, no universo dos 5.565 municípios brasileiros, segundo o Atlas do Desenvolvimento Humano no Brasil (2010).

\footnotetext{
${ }^{5}$ No âmbito internacional, Porto Alegre ganhou reconhecimento da ONU, especificamente em 1996, tornando-se um modelo de gestão participativa globalizada.
} 


\section{EVOLUÇÃO HISTÓRICA DO ORÇAMENTO PARTICIPATIVO}

Os precedentes do que hoje se denomina Orçamento Participativo já presentes, no território brasileiro, desde o final da década de 1970, quando algumas cidades brasileiras, a exemplo de Lajes, em Santa Catarina e Boa Esperança, no Espírito Santo, - entre os anos de 1978 e 1982, sob governos de diferentes partidos -, procuraram estabelecer um diálogo, ou intensificar as relações entre prefeitura e população, principalmente nos bairros periféricos carentes de infraestrutura. Tais precedentes chamaram a atenção em todo o Brasil, e terminaram por incentivar outras cidades a se engajarem na organização de associações de bairros, de moradores ou de amigos de bairros, sempre no intuito de fomentar a participação dos cidadãos na gestão municipal (PIRES, 2000).

É na década de 1980 que surge a denominação "orçamento participativo", até então aplicado de forma limitada ao plano municipal. No final dos anos 1990, entretanto, mecanismos de consulta no âmbito de matérias orçamentárias passaram a ser feitos também por alguns governos estaduais (PAIVA, 2006).

Neste período foi realizada uma série de eventos sobre o tema, com destaque para o I Congresso Brasileiro de Controle Social do Orçamento Público, em Belo Horizonte, Minas Gerais, em 1999, e para o Seminário Nacional de Orçamento Participativo, em São Luís, Maranhão, em 2003. No Estado de São Paulo foram organizados três congressos sobre o Orçamento Participativo e a participação popular, entre 2000 e 2003, nos municípios de Rio Claro, Araraquara e Campinas, respectivamente. No mesmo período, ocorreram, no Brasil e no exterior, fóruns e seminários internacionais de democracia participativa, nos quais o Orçamento Participativo foi um dos principais temas (PIRES, 2000).

Numa perspectiva política, as décadas de 1980 e 1990, foram palco de grandes transformações, que se deram no contexto do processo de redemocratização do país, acompanhada de um maior grau de descentralização política-administrativa, a partir do reconhecimento dos municípios como entes federativos autônomos, conforme $\mathrm{CF} / 88$. Do ponto de vista econômico-social, o período se notabilizou pela intensificação do processo histórico de profunda desigualdade, o que provocou a emersão de novas formas de pensar e agir no campo das políticas públicas (BRANDÃO, 2014).

Neste contexto histórico, a participação de maiores parcelas da população se consolidou a partir das experiências decorrentes da rejeição ao regime de ditadura militar, de modo a fomentar manifestações públicas contra o desemprego, contra a dívida externa, pela reforma 
agrária, pela proteção trabalhista e pela cobertura dos riscos sociais, entre outras questões de caráter geral (VAINER, 2000, p. 46).

A importância histórica de Porto Alegre no contexto do Orçamento Participativo, transcende o sucesso da iniciativa, no que se refere aos seus aspectos técnicos, para assumir um marco simbólico. Trata-se de uma cidade de grandes dimensões, multiétnica e multicultural, localizada na América Latina, num país recém-saído de um período longo de restrição a direitos civis e sociais, e privada do exercício da democracia. Por todo o contexto, em que se encontrava envolvida, Porto Alegre ${ }^{6}$ passou a ser uma referência em todo o mundo:

Apesar das limitações, Porto Alegre tem sido a mais importante referência transacional para o orçamento participativo e segue sendo uma das experiências mais fascinantes. $\mathrm{O}$ processo convenceu ativistas antiglobalização, assim como governos locais e assessores de organismos internacionais, como o Banco Mundial e o PNUD (SINTOMER; HERZBERG; RÖCKE, 2012. p. 80).

Foi, sobretudo, a condição de símbolo de democracia participativa, por meio da tomada de decisões compartilhadas no plano do Orçamento Público, que permitiu que Porto Alegre assumisse uma posição de destaque em todo o mundo:

O ponto de virada na difusão do OP é um marco que representa a passagem da experiência local à difusão massiva. $\mathrm{O}$ processo que leva à proliferação em escala planetária do OP é estimulado por uma pletora de atores numa relação interativa entre indivíduos e instituições. Assim, Porto Alegre continua aos olhos do mundo a capital da democracia. (OLIVEIRA, 2016, p. 229).

A partir desta experiência, o Orçamento Participativo foi adotado por esferas governamentais de distintos países da América Latina e da Europa. Destacam-se os municípios de Buenos Aires, Córdoba e Rosário, as três áreas urbanas mais populosas da Argentina; Montevidéu, no Uruguai; Assunção, no Paraguai; Negrete e Monte Pátria, Chile; Cidade do México; Cantón Morona, no Equador; Villa El Salvador, no Peru; Saint Denis, na França; Barcelona e San Sebastián, na Espanha (PIRES, 2000). Essa difusão do Orçamento Participativo, nos últimos anos a partir dos anos 1980, tem sido acompanhada de uma série de debates públicos, com vistas a avaliar as diversas experiências realizadas (PIRES, 2000).

Em todas as análises e em todas as experiências, que envolvem o Orçamento Participativo, há um consenso em torno da ideia de que a metodologia adotada, no processo de elaboração do Orçamento Participativo, promove maior inserção da população nos processos

\footnotetext{
${ }^{6}$ No âmbito internacional, Porto Alegre ganhou reconhecimento da ONU, especificamente em 1996, tornando-se um modelo de gestão participativa globalizada (FEDOZZI, 2009).
} 
políticos de tomada de decisões e, por conseguinte, contribui para a amadurecimento do sistema democrático.

\section{SOBRE O ORÇAMENTO PARTICIPATIVO}

O orçamento participativo é um instrumento de democracia representativa, que permite que o cidadão debata e participe do processo de definição dos destinos da sua cidade. Por meio dele, a população define as prioridades de investimentos, em obras e serviços, que serão realizados a cada ano, com recursos de orçamentos da prefeitura (BRASIL, 2015), mas se trata de um processo que extrapola a questão estrita do financiamento público, para assumir uma dimensão de pertencimento a um determinado território e uma determinada coletividade.

Em geral, não há dispositivos legais que obriguem a esta forma de proceder na elaboração do orçamento público. Entretanto, ali onde tem lugar, o processo de orçamento participativo é realizado pelo governo municipal através de consultas à população, por meio de reuniões abertas à sociedade, sobre as suas demandas e prioridades, e a partir daí procede-se à inclusão no projeto de Lei Orçamentária Anual (LOA). As reuniões, conduzidas pela própria administração municipal, costumam ser realizadas em locais distintos do município, e a comunidade elege uma pauta de demandas e seleciona, de acordo com seus critérios, prioridades que poderão ser acolhidas pela administração municipal.

O orçamento participativo, segundo Pires (2001, p. 13), representa "uma modalidade de participação popular que teve início e vem se consolidando num contexto específico do desenvolvimento socioeconômico e da vida política brasileira". Fedozzi acrescenta que o orçamento participativo evidencia uma:

[...] modalidade de gestão pública baseada na participação direta da população nas diversas fases que compõem a elaboração e execução do orçamento público municipal, especialmente na indicação das prioridades para alocação dos recursos de investimentos (FEDOZZI, 2001, p.97).

A análise dos procedimentos referentes ao Orçamento Participativo permite verificar que o mesmo viabiliza a efetivação da soberania popular, que em termos tradicionais costuma se encerrar com o exercício do voto em eleições gerais, e passa a estar presente na tomada de decisões referentes à alocação dos recursos públicos. Coo explica Gohn: 
a soberania popular passa a ser o critério norteador e fundamento básico para a aplicação dos recursos e programas públicos (GOHN, 2001, p. 1215).

O Orçamento Participativo apresenta também uma dimensão de controle social sobre o Estado (KHAIR, 2001), na medida em que contribui para a diminuição das interferências políticas pautadas nas relações de clientelismo, e qualifica a coparticipação entre governo e comunidade. Nas discussões tendentes à elaboração da proposta orçamentária a população tem condição de apresentar reivindicações, mas também abre oportunidade a que o governo exponha a situação financeira e os problemas operacionais. Dessa interação, surge uma tendência à elevação tanto da intensificação do controle social, como do seu nível de qualidade. Na linha do que observam Genro e Souza $(2002$, p. 8) "com o OP o cidadão deixa de ser um simples coadjuvante para ser protagonista ativo da gestão pública".

A efetivação do Orçamento Participativo, em qualquer dos três planos de governo, se dá de forma alinhada com o que é a estrutura legislativa, na qual está disposto o orçamento público. Conforme estabelecido na $\mathrm{CF} / 88$, o orçamento deve estar disposto em uma estrutura legislativa tripartite, dividida em Lei do Plano Plurianual (PPA), Lei de Diretrizes Orçamentárias (LDO) e Lei Orçamentária Anual (LOA), conforme Quadro1, disposto a seguir:

\section{Quadro 1 - Instrumentos legislativos que compõem o Orçamento Público, conforme CF/88}

\begin{tabular}{|c|c|c|}
\hline \multicolumn{3}{|c|}{ INSTRUMENTOS } \\
\hline $\begin{array}{l}\text { Lei do Plano Plurianual } \\
\text { (PPA) }\end{array}$ & $\begin{array}{c}\text { Lei de Diretrizes } \\
\text { Orcamentárias (LDO) }\end{array}$ & $\begin{array}{c}\text { Lei Orçamentária Anual } \\
\text { (LOA) }\end{array}$ \\
\hline $\begin{array}{l}\text { Prevê as despesas com } \\
\text { programas, obras e serviços } \\
\text { decorrentes, que durem mais } \\
\text { de um ano. }\end{array}$ & $\begin{array}{l}\text { A partir do PPA, define metas e } \\
\text { prioridades orçamentárias, } \\
\text { estabelece orientações de como } \\
\text { elaborar o orçamento anual, e } \\
\text { se tornou a partir da Lei de } \\
\text { Responsabilidade Fiscal, o } \\
\text { principal instrumento de } \\
\text { avaliação das contas públicas. }\end{array}$ & $\begin{array}{l}\text { Consiste no orçamento } \\
\text { propriamente dito, com } \\
\text { previsão de receitas e } \\
\text { despesas, sempre em } \\
\text { conformidade com o PPA e } \\
\text { a LDO. }\end{array}$ \\
\hline \multicolumn{3}{|c|}{ Vigência } \\
\hline 4 anos & 1 ano & 1 ano \\
\hline
\end{tabular}

Fonte: Adaptado de VIGLIO, 2004, p. 35-36.

Os instrumentos indicados no quadro são elaborados pelo Poder Executivo, analisados e autorizados pelo Poder Legislativo, nos três entes da Federação. O Orçamento Participativo tem lugar na etapa de elaboração, mais precisamente no momento das definições sobre políticas 
públicas a serem adotadas. As propostas são encaminhadas para se integrarem ao PPA, LDO e LOA, para que possam ser aprovadas pelo Legislativo e devolvidas à sanção pelo Executivo.

\section{ESTRUTURAS COLEGIADAS DE GESTÃO, ORÇAMENTO PARTICIPATIVO E GOVERNANÇA SOLIDÁRIA LOCAL}

De acordo com o Manual Modelo de Gestão, da Prefeitura Municipal de Porto Alegre (2014), a fim de implementar o Orçamento Participativo, foram criadas as estruturas colegiadas de gestão. Estas estruturas correspondem aos órgãos responsáveis pelos procedimentos referentes à elaboração daquele instrumento, e estão constituídos de dirigentes públicos, servidores e lideranças da sociedade civil. São eles os responsáveis diretos pela organização e dinâmica das discussões, que se dão sempre de forma colegiada, com a divisão em programas de trabalho, e realização de conferências, encontros e reuniões de acompanhamento e tomada de decisões.

Em 2014 foi criada a figura do agente de planejamento e gestão local, que deve atuar diretamente junto aos líderes de ação e servidores dos órgãos para a execução das ações dos programas estratégicos. Tais agentes são ligados à Secretaria de Planejamento Estratégico e Orçamento, e articulam-se diretamente com os gerentes de programas e com todos os órgãos do município, constituindo mais um instrumento de disseminação da cultura do planejamento estratégico junto aos órgãos (PORTO ALEGRE, 2014).

Os distintos grupos de trabalho, que constam relacionados no Quadro 2, interagem entre si de forma contínua, a fim de aperfeiçoar as decisões, de forma a evitar lacunas ou sobreposição de deliberações.

Quadro 2 - Grupos de trabalho ligados ao Orçamento Participativo da Prefeitura de Porto Alegre 2014

\begin{tabular}{|c|c|c|c|c|c|}
\hline Reunião & Quem & Porque & $\begin{array}{c}\text { Quand } \\
\text { o }\end{array}$ & O que & Resultados \\
\hline $\begin{array}{l}\text { PLANO DE } \\
\text { GOVERNO/ } \\
\text { ESTRATÉGI } \\
\text { A Reuniões } \\
\text { de Análise da } \\
\text { Estratégia } \\
\text { (RAE) }\end{array}$ & $\begin{array}{l}\text { Prefeito, Vice- } \\
\text { Prefeito, } \\
\text { Secretários e } \\
\text { Presidentes dos } \\
\text { Órgãos e } \\
\text { Gerente dos } \\
\text { Programas }\end{array}$ & $\begin{array}{c}\text { Acompanhar os } \\
\text { resultados } \\
\text { estratégicos, } \\
\text { alinhados ao plano } \\
\text { de governo, } \\
\text { definindo correções } \\
\text { e/ou ajustes. }\end{array}$ & $\begin{array}{c}\text { Semestr } \\
\text { al }\end{array}$ & $\begin{array}{c}\text { Mapa } \\
\text { Estratégico, } \\
\text { Programas, } \\
\text { Plano de } \\
\text { Governo }\end{array}$ & $\begin{array}{c}\text { Ajustes nos } \\
\text { Programas e } \\
\text { na } \\
\text { estratégia }\end{array}$ \\
\hline
\end{tabular}




\begin{tabular}{|c|c|c|c|c|c|}
\hline $\begin{array}{l}\text { POLÍTICA E } \\
\text { DIRECION } \\
\text { ADORES } \\
\text { Comitê } \\
\text { Gestor de } 1^{\mathrm{a}} \\
\text { Instância }\end{array}$ & $\begin{array}{l}\text { Prefeito, Vice- } \\
\text { Prefeito e } \\
\text { Secretários: } \\
\text { Representantes } \\
\text { políticos dos } \\
\text { partidos que } \\
\text { compõem o } \\
\text { governo + SMF, } \\
\text { SMGES, } \\
\text { SMPEO e } \\
\text { SMGL. }\end{array}$ & $\begin{array}{l}\text { Definir grandes } \\
\text { direcionadores, } \\
\text { assim como } \\
\text { promover tomada de } \\
\text { decisão não sanadas } \\
\text { nos outros fóruns }\end{array}$ & $\begin{array}{l}\text { Semana } \\
\text { l ou sob } \\
\text { demand } \\
\text { a }\end{array}$ & $\begin{array}{l}\text { Questões } \\
\text { críticas do } \\
\text { dia a dia do } \\
\text { Governo e } \\
\quad \text { dos } \\
\text { Programas }\end{array}$ & $\begin{array}{c}\text { Direcionado } \\
\text { res de } \\
\text { Governo }\end{array}$ \\
\hline $\begin{array}{l}\text { PROGRAM } \\
\text { AS, } \\
\text { ORÇAMEN } \\
\text { TO E } \\
\text { QUESTÕES } \\
\text { CRÍTICAS } \\
\text { Comitê } \\
\text { Gestor de } 2^{\mathrm{a}} \\
\text { Instância } \\
\end{array}$ & $\begin{array}{c}\text { Secretários: } \\
\text { SMF, SMGES, } \\
\text { SMA, SMPEO, } \\
\text { SMGL. }\end{array}$ & $\begin{array}{c}\text { Acompanhar a } \\
\text { execução } \\
\text { orçamentária e } \\
\text { financeira, além de } \\
\text { solucionar questões } \\
\text { críticas do dia a dia } \\
\text { do Governo, assim } \\
\text { como da Execução } \\
\text { dos Programas }\end{array}$ & $\begin{array}{l}\text { Bissem } \\
\text { anal ou } \\
\text { sob } \\
\text { demand } \\
\text { a }\end{array}$ & $\begin{array}{c}\text { Execução } \\
\text { Orçamentária } \\
\text { e Financeira, } \\
\text { PL, questões } \\
\text { críticas do } \\
\text { dia a dia do } \\
\text { Governo e } \\
\text { dos } \\
\text { Programas }\end{array}$ & $\begin{array}{l}\text { Ajustes no } \\
\text { Orçamento } \\
\text { Liberação } \\
\text { de PL, } \\
\text { direcionado } \\
\text { res de } \\
\text { governo }\end{array}$ \\
\hline $\begin{array}{c}\text { CONTRATO } \\
\text { S DE } \\
\text { GESTÃO } \\
\text { Reuniões de } \\
\text { Acompanha } \\
\text { mento } \\
\text { Trimestral } \\
\text { (RAT) } \\
\end{array}$ & $\begin{array}{l}\text { Prefeito, Vice- } \\
\text { Prefeito, } \\
\text { Secretários e } \\
\text { Presidentes de } \\
\text { Órgãos e } \\
\text { Gerentes dos } \\
\text { Programas }\end{array}$ & $\begin{array}{c}\text { Acompanhar os } \\
\text { resultados firmados } \\
\text { nos Contratos de } \\
\text { Gestão e realizar } \\
\text { ajustes }\end{array}$ & $\begin{array}{l}\text { Trimest } \\
\text { ral }\end{array}$ & $\begin{array}{l}\text { Visão geral } \\
\text { dos } \\
\text { resultados e } \\
\text { Contrato de } \\
\text { Gestão de } \\
\text { cada } \\
\text { Secretaria e } \\
\text { Órgão } \\
\end{array}$ & $\begin{array}{l}\text { Status de } \\
\text { Evolução } \\
\text { dos } \\
\text { resultados. } \\
\text { Encaminhar } \\
\text { para } \\
\text { correção }\end{array}$ \\
\hline $\begin{array}{c}\text { CONTRATO } \\
\text { S DE } \\
\text { GESTÃO } \\
\text { Reuniões de } \\
\text { Acompanha } \\
\text { mento } \\
\text { Mensal } \\
\text { (RAM) }\end{array}$ & $\begin{array}{l}\text { Vice-Prefeito, } \\
\text { Secretários e } \\
\text { Presidentes de } \\
\text { Órgãos, e } \\
\text { Gerentes dos } \\
\text { Programas }\end{array}$ & $\begin{array}{l}\text { Acompanhar os } \\
\text { resultados firmados } \\
\text { nos Contratos de } \\
\text { Gestão }\end{array}$ & Mensal & $\begin{array}{l}\text { Contrato de } \\
\text { Gestão de } \\
\text { cada } \\
\text { Secretaria e } \\
\text { Órgão }\end{array}$ & $\begin{array}{c}\text { Status de } \\
\text { Evolução. } \\
\text { Encaminhar } \\
\text { para } \\
\text { correção }\end{array}$ \\
\hline $\begin{array}{l}\text { PAINEL DE } \\
\text { GESTÃO } \\
\text { Reuniões de } \\
\text { Gestão em } \\
\text { cada } \\
\text { Secretaria e } \\
\text { Órgão (RG) }\end{array}$ & $\begin{array}{l}\text { Secretário e } \\
\text { Presidente de } \\
\text { Órgão, com suas } \\
\text { respectivas } \\
\text { equipes de } \\
\text { Líderes, Agente } \\
\text { Local (SMPEO) } \\
\text { e Gerentes dos } \\
\text { Programas }\end{array}$ & $\begin{array}{l}\text { Acompanhar a } \\
\text { gestão em cada } \\
\text { Secretaria, a partir } \\
\text { dos respectivos } \\
\text { Painéis de Gestão. } \\
\text { São os antigos } \\
\text { Núcleo Gestores }\end{array}$ & Mensal & $\begin{array}{l}\text { Painel de } \\
\text { Gestão de } \\
\text { cada } \\
\text { Secretaria e } \\
\text { Órgão }\end{array}$ & $\begin{array}{c}\text { Status de } \\
\text { evolução. } \\
\text { Encaminhar } \\
\text { para } \\
\text { correção }\end{array}$ \\
\hline $\begin{array}{c}\text { PROGRAM } \\
\text { AS }\end{array}$ & $\begin{array}{l}\text { Vice-Prefeito e } \\
\text { Secretários e } \\
\text { Presidentes de }\end{array}$ & $\begin{array}{l}\text { Promover a gestão } \\
\text { colegiada dos } \\
\text { Programas, }\end{array}$ & Mensal & $\begin{array}{c}\text { Físico- } \\
\text { financeiro de } \\
\text { cada } \\
\end{array}$ & $\begin{array}{c}\text { Status de } \\
\text { evolução. } \\
\text { Encaminhar }\end{array}$ \\
\hline
\end{tabular}




\begin{tabular}{|c|c|c|c|c|c|}
\hline $\begin{array}{l}\text { Comitês de } \\
\text { Gerenciamen } \\
\text { to }(\mathrm{CG})\end{array}$ & $\begin{array}{c}\text { Órgãos } \\
\text { relacionados ao } \\
\text { respectivo } \\
\text { Programa, o } \\
\text { Gerente do } \\
\text { Programa e } \\
\text { líderes de ação } \\
\end{array}$ & $\begin{array}{c}\text { validando e } \\
\text { discutindo ajustes } \\
\text { que se façam } \\
\text { necessários }\end{array}$ & & $\begin{array}{l}\text { Programa } \\
\text { (conjunto de } \\
\text { ações) }\end{array}$ & $\begin{array}{c}\text { para } \\
\text { correção }\end{array}$ \\
\hline $\begin{array}{l}\text { PROGRAM } \\
\text { AS } \\
\text { Grupos de } \\
\text { Trabalho } \\
\text { Geral (GTG) }\end{array}$ & $\begin{array}{l}\text { Gerente do } \\
\text { Programa, com } \\
\text { todos os } \\
\text { respectivos } \\
\text { líderes das ações }\end{array}$ & $\begin{array}{l}\text { Promover a gestão } \\
\text { colegiada dos } \\
\text { Programas, } \\
\text { levantando pontos } \\
\text { críticos e riscos, e } \\
\text { propondo ajustes que } \\
\text { se façam necessários }\end{array}$ & Mensal & $\begin{array}{c}\text { Físico- } \\
\text { financeiro de } \\
\text { cada } \\
\text { Programa } \\
\text { (conjunto de } \\
\text { ações) }\end{array}$ & $\begin{array}{l}\text { Status de } \\
\text { evolução. } \\
\text { Diagnostica } \\
\text { r riscos. } \\
\text { Propor } \\
\text { medidas } \\
\text { corretivas }\end{array}$ \\
\hline $\begin{array}{l}\text { AÇÕES } \\
\text { Grupos de } \\
\text { Trabalho } \\
\text { (GT) }\end{array}$ & $\begin{array}{c}\text { Cada líder de } \\
\text { ação com agente } \\
\text { local }\end{array}$ & $\begin{array}{l}\text { Promover a ação de } \\
\text { cada gestão }\end{array}$ & $\begin{array}{c}\text { Semana } \\
1\end{array}$ & $\begin{array}{c}\text { Físico- } \\
\text { financeiro de } \\
\text { cada ação }\end{array}$ & $\begin{array}{l}\text { Status de } \\
\text { evolução. } \\
\text { Diagnóstico } \\
\text { de riscos. } \\
\text { Propor } \\
\text { correção }\end{array}$ \\
\hline $\begin{array}{l}\text { Comitê } \\
\text { Gestor do } \\
\text { Território }\end{array}$ & $\begin{array}{c}\text { Centro } \\
\text { Administrativo } \\
\text { Regional. } \\
\text { Representantes } \\
\text { de todos os } \\
\text { órgãos com } \\
\text { atuação em cada } \\
\text { uma das regiões. } \\
\text { Fórum Regional } \\
\text { da OP }\end{array}$ & $\begin{array}{l}\text { Aproximar a } \\
\text { Prefeitura da } \\
\text { Comunidade e } \\
\text { qualificar os } \\
\text { serviços. }\end{array}$ & Mensal & $\begin{array}{c}\text { Planejar, } \\
\text { articular e } \\
\text { monitorar a } \\
\text { ações do } \\
\text { governo em } \\
\text { cada uma das } \\
17 \text { regiões } \\
\text { administrativ } \\
\text { as }\end{array}$ & $\begin{array}{c}\text { Status da } \\
\text { qualidade } \\
\text { dos serviços }\end{array}$ \\
\hline
\end{tabular}

Fonte: adaptado a partir de PORTO ALEGRE, 2014, s.n.

A estrutura responsável pela discussão e elaboração do Orçamento Participativo de Porto Alegre divide-se em 17 regiões, nas quais são realizadas as discussões, sendo que cada uma delas conta com a representação de dois conselheiros e dois suplentes. Por outro lado, são preestabelecidas seis temáticas a serem discutidas, em ordem de prioridades eleitas por demanda da população. Uma mesma região pode abranger diversos bairros.

O Quadro 3, abaixo, oferece uma visão geral sobre como se dá a estrutura territorial das discussões que envolvem o Orçamento Participativo, onde são elaboradas as plenárias divididas por prioridades de assuntos, eleitas em 2016, para execução em 2017. 
Quadro 3 - Regiões do OP com prioridades eleitas - 2016-2017

\begin{tabular}{|l|c|l|}
\hline \multicolumn{2}{|c|}{ REGIÕES DO ORÇAMENTO PARTICIPATIVO } \\
\hline & Bairros/ Arquipélago & $\begin{array}{l}\text { Prioridades eleitas 2016-2017 } \\
\text { (demandas da população) }\end{array}$ \\
\hline $\begin{array}{l}\text { Região 01 - Humaitá- } \\
\text { Navegantes }\end{array}$ & 5 & $1^{\circ}$ lugar: Habitação \\
\hline Região 02 - Noroeste & 13 & $1^{\circ}$ lugar: Saúde \\
\hline Região 03 - Leste & 8 & $1^{\circ}$ lugar: Educação \\
\hline Região 04 - Lomba do Pinheiro & 2 & $1^{\circ}$ lugar: Pavimentação \\
\hline Região 05 - Norte & 1 & $1^{\circ}$ lugar: Habitação \\
\hline Região 06 - Nordeste & 1 & $1^{\circ}$ lugar: Saúde \\
\hline Região 07 - Partenon & 5 & $1^{\circ}$ lugar: Habitação \\
\hline Região 08 - Restinga & 1 & $1^{\circ}$ lugar: Educação \\
\hline Região 09 - Glória & 4 & $1^{\circ}$ lugar: Habitação \\
\hline Região 10 - Cruzeiro & 2 & $1^{\circ}$ lugar: Assistência Social \\
\hline Região 11 - Cristal & 1 & $1^{\circ}$ lugar: Habitação \\
\hline Região 12 - Centro-Sul & 6 & $1^{\circ}$ lugar: Habitação \\
\hline Região 13 - Extremo Sul & 5 & $1^{\circ}$ lugar: Assistência Social \\
\hline Região 14 - Eixo Baltazar & 2 & $1^{\circ}$ lugar: Saúde \\
\hline Região 15 - Sul & 9 & $1^{\circ}$ lugar: Habitação \\
\hline Região 16 - Centro & 18 & $1^{\circ}$ lugar: Assistência Social \\
\hline $\begin{array}{l}\text { Região 17 - Ilhas } \\
\text { (Arquipélago) }\end{array}$ & 4 & $1^{\circ}$ lugar: Pavimentação \\
\hline Fonte: Adaptado de PORTO ALEGR & \\
\hline
\end{tabular}

Fonte: Adaptado de PORTO ALEGRE, 2018.

Já o Gráfico 1, evidencia os percentuais das prioridades eleitas no conjunto das regiões, onde se pode verificar que o tema da habitação foi o que contou com maior demanda da população, estando presente como a questão de maior interesse em mais de $40 \%$ das 17 regiões. 


\section{Gráfico 1 - Percentual de prioridades das temáticas eleitas por regiões do OP de Porto Alegre 2016/2017}

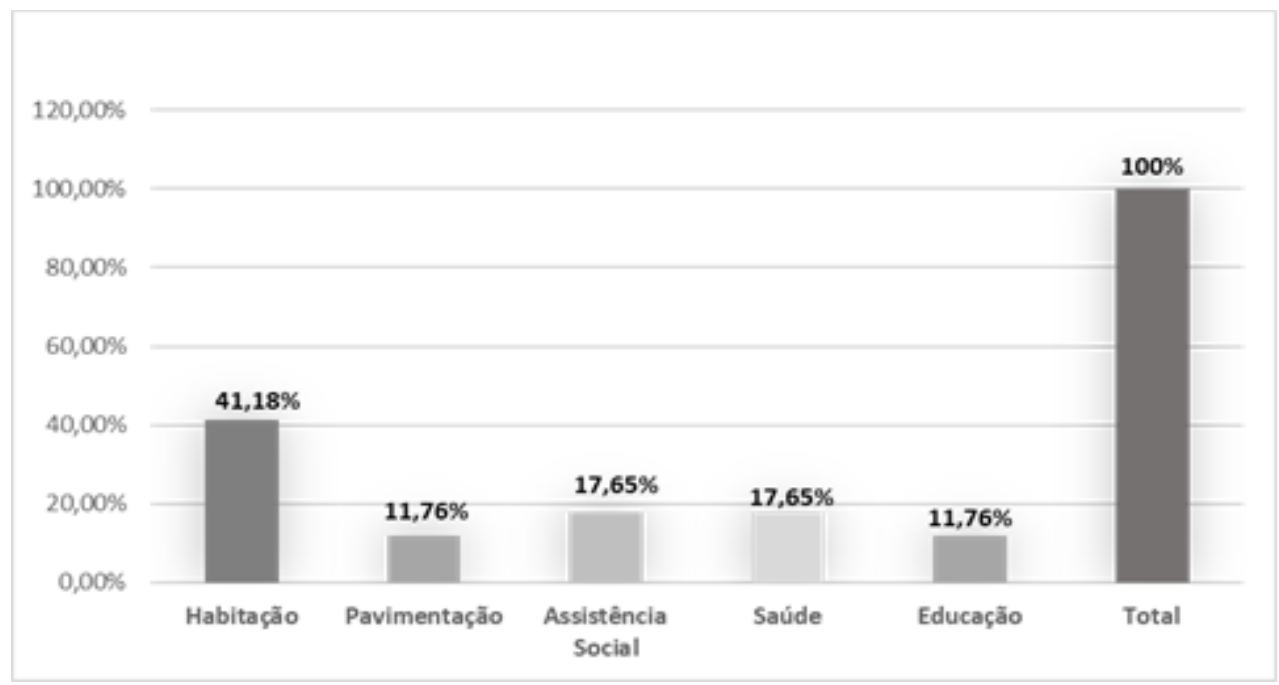

Fonte: PACHECO, 2018.

Os temas da assistência social e saúde ocuparam o $2^{\circ}$ lugar na ordem de prioridade, com $17,65 \%$ das indicações do conjunto das regiões, enquanto educação e pavimentação constituíram a $3^{\mathrm{a}}$ demanda em ordem de prioridade, com $11,76 \%$ das indicações.

Uma vez estabelecidas as temáticas em ordem de prioridade para discussão, cada região terá oportunidade de detalhar quais são os subtemas que constituirão a base para os debates, também em ordem de prioridade entre eles, conforme indicado no Quadro 4:

Quadro 4 - Subtemas do Orçamento Participativo e as prioridades eleitas - 2016-2017.

\begin{tabular}{|c|c|}
\hline Temática & Ordem de prioridade \\
\hline Educação & $\begin{array}{l}1^{\circ} \text { lugar: Educação Infantil } \\
2^{\circ} \text { lugar: Educação Especial } \\
3^{\circ} \text { lugar: Educação para Jovens e Adultos } \\
4^{\circ} \text { lugar: Ensino Fundamental }\end{array}$ \\
\hline Esporte e Lazer & $\begin{array}{l}1^{\circ} \text { lugar: Reforma e Ampliação dos Centros Comunitários } \\
2^{\circ} \text { lugar: Equipamentos de Lazer e Recreação } \\
3^{\circ} \text { lugar: Esporte e Lazer } \\
4^{\circ} \text { lugar: Equipamentos Esportivos }\end{array}$ \\
\hline $\begin{array}{l}\text { Circulação, transporte e } \\
\text { mobilidade urbana }\end{array}$ & $\begin{array}{l}1^{\circ} \text { lugar: Qualificação de Terminais e Parada Seguras } \\
2^{\circ} \text { lugar: Pavimentação de Vias } \\
3^{\text {o }} \text { lugar: Programa Mobilidade e Organização do Espaço } \\
\text { Urbano - Abertura de Via e Rótulas } \\
4^{\circ} \text { lugar: Duplicação e Alargamento de Vias }\end{array}$ \\
\hline $\begin{array}{l}\text { Habitação, organização da } \\
\text { cidade, desenvolvimento } \\
\text { urbano e ambiental }\end{array}$ & $\begin{array}{l}1^{\circ} \text { lugar: Habitação } \\
2^{\circ} \text { lugar: Saneamento Básico } \\
3^{\circ} \text { lugar: Saneamento Ambiental } \\
4^{\circ} \text { lugar: Urbanismo }\end{array}$ \\
\hline
\end{tabular}




\begin{tabular}{|c|c|}
\hline $\begin{array}{l}\text { Desenvolvimento } \\
\text { econômico tributação, } \\
\text { turismo e trabalho }\end{array}$ & $\begin{array}{l}1^{\circ} \text { lugar: Geração de Trabalho e Renda, Apoio a Iniciativas } \\
\text { Populares e Cursos } \\
2^{\circ} \text { lugar: Qualificação de Trabalho e Renda } \\
3^{\circ} \text { lugar: Apoio a Empreendimentos } \\
4^{\circ} \text { lugar: Turismo }\end{array}$ \\
\hline Cultura & $\begin{array}{l}1^{\circ} \text { lugar: Atividade de Descentralização da Cultura } \\
2^{\circ} \text { lugar: Ações e Eventos da Cultura } \\
3^{\circ} \text { lugar: Equipamentos Culturais } \\
4^{\circ} \text { lugar: Juventude }\end{array}$ \\
\hline Saúde & $\begin{array}{l}1^{\circ} \text { lugar: Reforma, ampliação e construção de postos de saúde } \\
2^{\circ} \text { lugar: Construção e Ampliação da Rede Especializada } \\
3^{\circ} \text { lugar: Ampliação dos Serviços da Rede Básica } \\
4^{\circ} \text { lugar: Acessibilidade e Mobilidade Urbana }\end{array}$ \\
\hline Assistência social & $\begin{array}{l}1^{\circ} \text { lugar: Atendimento à criança e ao Adolescente } \\
2^{\circ} \text { lugar: Bolsa-Qualificação } \\
3^{\circ} \text { lugar: Atendimento ao Idoso } \\
4^{\circ} \text { lugar: Atendimento à Família }\end{array}$ \\
\hline
\end{tabular}

Fonte: Adaptado de PORTO ALEGRE, Prefeitura, 2014.

Segundo a Prefeitura Municipal de Porto Alegre (PORTO ALEGRE, 2018), a abrangência dos 17 temas, discutidos durante o processo de escolha, foram direcionadas para as obras e serviços. Ressalte-se que essas permaneceram como as prioridades do OP, nos anos estabelecidos. Nesse caso, a população estabeleceu uma ordem de prioridades, para os investimentos anuais, de acordo com esses temas e, também, classificou suas demandas nessas prioridades.

\section{A IMPLEMENTAÇÃO DA GOVERNANÇA SOLIDÁRIA LOCAL NO MUNICÍPIO DE PORTO ALEGRE}

$\mathrm{Na}$ busca por soluções e resultados de problemas habituais a sociedade e o poder local se unem em uma ação conjunta. A gestão realizada de forma solidária entre a administração e a sociedade tem como resultado, não só influenciar a tomada de decisões de governo, mas fomentar o envolvimento nas questões importantes para toda a comunidade (GOMES, 2003).

Em meados de 2005, a prefeitura de Porto Alegre reformulou o seu modelo de gerir as questões, relacionadas às políticas públicas. Estruturada no modelo da pluralidade, do diálogo e do consenso, a comunidade foi trazida a participar de forma mais estreita, de forma a integrarse com a realização de projetos e assumir responsabilidades públicas. O modelo formulado pela prefeitura teve como característica a concentração de todos os esforços para realização de ações 
inerentes a um mesmo ponto estratégico, com a definição precisa de objetivos de médio e longo prazos.

Cada objetivo era sustentado por programas de governo, a serem avaliados a partir da análise de indicadores, que incluíam metas a serem alcançadas, o que permitiu o acompanhamento da efetivação das ações. É em torno desta concepção que se estabeleceu naquele município a chamada Governança Solidária Local (GSL), com a missão de ser referência em qualidade de vida. Assim, o entendimento da Governança Solidária Local está relacionado a uma

...gestão de base territorial que promove a integração entre governo e sociedade numa parceria baseada nos princípios de participação, autonomia, transversalidade e na corresponsabilidade orientada em favor da inclusão social (PORTO ALEGRE. Prefeitura, 2018).

Toda a prefeitura foi reestruturada, assumindo compromissos de oferecimento de políticas públicas, e tendo como objetivo a prestação de serviços de qualidade e atendimento das necessidades da população, e de forma a fomentar o desenvolvimento local (BUSATTO, 2005; MATIAS-PEREIRA, 2010, p. 110; BANCO MUNDIAL, 1992, p. 5, 11; Milani e Solinis, 2002).

No documento de referência sobre o tema, elaborado pela prefeitura municipal, (PORTO ALEGRE. Prefeitura, 2006, p. 13), encontrava-se, já em 2006, a "Justificativa Política", do Programa de Governança Solidária Local, segundo o qual a cidade precisa

...dar continuidade à democracia participativa [...], avançando para formas menos adversárias e mais cooperativas [...], dentro de uma visão ampliada de governança, em que a influência e o exercício do controle social, dos munícipes, possam se dar de várias maneiras, proativas e propositivas, ao invés de apenas reativas e reivindicativas.

Na tomada de decisão, deve-se recorrer a um grande processo de diálogo, por meio do qual seja possível demonstrar os interesses em discussão, em confronto com a realidade financeira em todos os setores envolvidos, com o fim de construir consensos. No processo de decisão, segundo Batista (2009), não há uma única maneira correta para avaliar um risco, sendo necessária a coexistência sadia e a comunhão de diferenças, tanto para fins de reconhecimento dos problemas comuns, como também daqueles que sejam específicos, e das suas respectivas dimensões, no intuito de apresentar soluções justas. Trata-se de um processo que possibilita a construção de redes de diálogo, dotadas de solidariedade, colaboração e cooperação entre todos 
os envolvidos, na busca da efetivação do interesse coletivo. Em definitiva, trata-se de promover uma governança humanizada.

A responsabilidade, num processo de governança solidária e humanizada é distribuída entre todos os cidadãos, que deixam de ser apenas destinatários de políticas, para assumirem também a condição de agentes de construção da agenda deliberativa de tais políticas. $\mathrm{O}$ Orçamento Participativo elaborado segundo tais premissas contribui para o processo de agregação de informações, diagnóstico das necessidades, tomada de conhecimento da realidade coletiva, respeito à diversidade, e engajamento político com vistas à resolução de questões de interesse público (FERRAREZI; OLIVEIRA, 2010).

O Programa de Governança Solidária Local (PGSL) de Porto Alegre é voltado à articulação de redes de participação política, tendo em vista a experimentação inovadora de um novo padrão de relação entre a prefeitura e sociedade. É "governança" na medida em que se baseia na parceria entre governo local e sociedade, e estimula a participação social, o protagonismo e o empreendedorismo dos cidadãos e a sua corresponsabilidade na gestão das ações públicas. É “solidária”, pois baseada na cooperação entre as instituições governamentais, de nível municipal, estadual e federal, não-governamentais, bem como entre voluntários que se disponham a participar da iniciativa. Finalmente, é "local" porque estas redes têm como base a territorialidade constituída pelas regiões do município, suas vilas e bairros.

O modelo adotado pela prefeitura de Porto Alegre aplicou o conceito de Governança Solidária Local com estruturação por eixos de atuação e a contínua avaliação de resultados. Os diferentes ciclos de monitoramento e controle são realizados nos níveis operacional, tático e estratégico, conforme disposto no organograma constante na Figura 1.

Figura 1 - Visão sistêmica do modelo de gestão da Prefeitura de Porto Alegre 


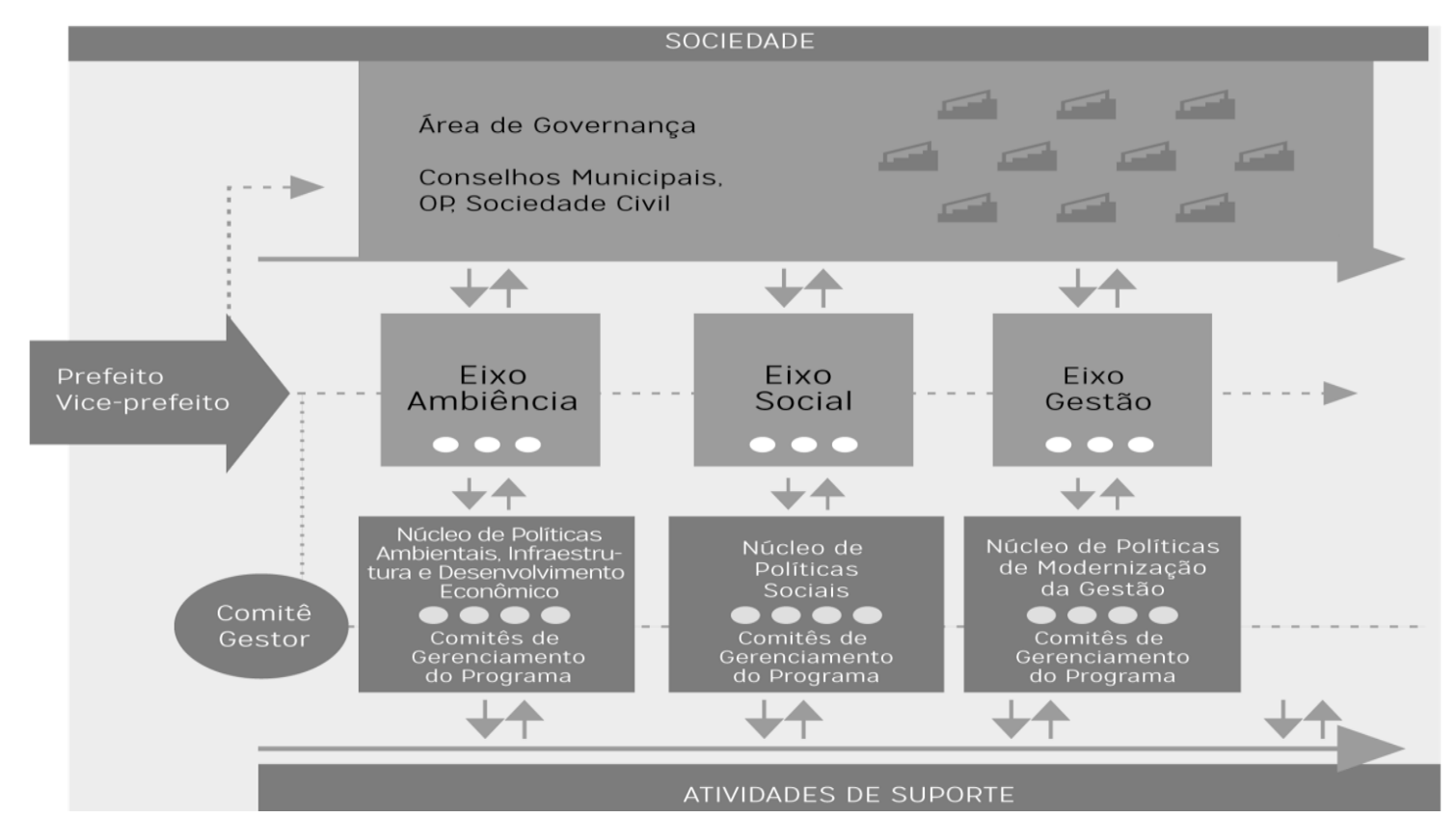

Fonte: PORTO ALEGRE. Prefeitura, 2014, p. 19.

O organograma da Figura 1 dá a visão sistêmica apresentada pela prefeitura de Porto Alegre, que adotou como premissa a transversalidade, de forma a articular, por um lado, a integração de várias secretarias e órgãos na execução das ações dos Programas Estratégicos, e por outro a territorialidade, de forma a considerar a participação das suas 17 regiões. Este desenho respeita a tradição da cidade na participação popular e na convivência das diferenças existentes entre suas diversas regiões. Respeita ademais a transparência, que permite a todos os cidadãos conferirem, no Portal de Gestão, o andamento dos Programas, bem como a liderança, que viabiliza a tomada de posição dos indivíduos em seus diversos campos de atuação (PORTO ALEGRE, 2014).

Isso reforça o parecer que já tinha sido previsto por Cabannes (2004, p. 17), que exaltou a governança, não como governo, mas como "conceito que reconhece que o poder existe dentro e fora da autoridade formal e instituições governamentais". A gestão participativa da autoridade formal em consonância com o Orçamento Participativo, gerenciando a execução de projetos através de visão sistêmica, transforma democraticamente a sua prática com capacidade de governança.

Os principais benefícios propiciados pelo Portal de Gestão disponibilizado pela prefeitura de Porto Alegre e que é estruturado segundo este modelo gerencial podem ser sistematizados da seguinte forma: 
- Sistema on-line de gestão: as informações estão disponíveis, atualizadas e armazenadas em um único local. O desenvolvimento de uma ferramenta de gestão via internet proporciona a pesquisa, consulta e o contínuo monitoramento dos programas, execução orçamentária, cronogramas de projetos, situação de atendimento das demandas priorizadas através do Orçamento Participativo, indicadores, metas e demais aspectos relevantes. O Portal garante este acesso contínuo às informações a todos os profissionais envolvidos.

- Democratização e transparência da informação: [...] absoluta acessibilidade às informações administrativas. Neste sentido, o Portal de Gestão elimina a segregação interdepartamental e a fragmentação típicas das administrações, principalmente públicas.

- Descentralização da gestão: [...] A implantação do Portal auxilia a formação de lideranças, em diversos níveis da hierarquia administrativa, reforçando o papel do gestor e evitando a centralização decisória em aspectos que possam permitir a tomada de decisão descentralizada.

- Suporte à organização das estruturas coletivas de gestão: o Portal é um recurso facilitador para o adequado funcionamento das Estruturas Coletivas, tornando-as habilitadas a analisar e inserir informações, em tempo real, referentes à situação dos Programas, ações, etapas, cronogramas de projetos, atas de reuniões e outros dados. Desta forma, caracteriza-se como uma ferramenta indispensável para a gestão, fortalecendo também a estrutura coletiva e descentralizada do trabalho.

- Agilidade na tomada de decisão: dada a possibilidade de a informação estar disponível de forma organizada e atualizada, o processo coletivo de decisão dispõe de dados e fatos para se consolidar, sendo bastante facilitado e acelerado.

- Base para concessão de verbas remuneratórias: visando à concessão de gratificações baseadas pelo atingimento de metas, o Portal de Gestão acompanha sistematicamente indicadores institucionais que permitem avaliar os resultados atingidos pelas diversas áreas e categorias profissionais que atuam nos Programas do município.

- Sistema permanente de educação a distância: o recurso da internet proporciona treinamento e aprendizado à distância, relativo ao novo Modelo de Gestão para os públicos mais diversos e dispersos, ajudando a qualificar o maior número possível de gestores, habilitando-os a conduzir os programas de governo e respectivas definições estratégicas, conforme as competências e responsabilidades associadas (PORTO ALEGRE, 2014, p. 23-24).

O papel da Prefeitura, junto à população, é o de aumentar o potencial de ação, existente na sociedade, de forma a promover a cooperação de todos em favor de objetivos comuns. $\mathrm{O}$ principal conceito que sustenta esse esforço em Porto Alegre é o de "governança solidária local”. Por esta razão foi viabilizada a construção da Visão Sistêmica do Modelo de Gestão (Figura 1), que mostra a forma como o governo municipal se articula de maneira a atender aos interesses da população. 


\section{PARTICIPAÇÃO DA POPULAÇÃO NAS ASSEMBLEIAS REGIONAIS E TEMÁTICAS DO OP, EM PORTO ALEGRE/RS DE 2011 A 2016}

A experiência de participação popular de Porto Alegre foi construída ao longo dos anos, numa estreita relação entre cidadãos e o poder local, tendo o Orçamento Participativo como uma ferramenta que fomenta e instrumentaliza o exercício da democracia. Atualmente, Porto Alegre tem um dos melhores índices de IDHM do país e no âmbito internacional obteve o reconhecimento da ONU, em 1996, tornando-se um modelo de gestão participativa globalizada em todo o mundo. A Tabela 1 expõe a evolução da participação da comunidade nas assembleias temáticas do Orçamento Participativo em cada uma das regiões do Município, entre 2011 e 2016:

Tabela 1 - Votantes por região nas assembleias temáticas do Orçamento Participativo de Porto Alegre entre 2011 e 2016

\begin{tabular}{l|c|c|c|c|c|c|c}
\hline Região/ano & $\mathbf{2 0 1 1}$ & $\mathbf{2 0 1 2}$ & $\mathbf{2 0 1 3}$ & $\mathbf{2 0 1 4}$ & $\mathbf{2 0 1 5}$ & $\mathbf{2 0 1 6}$ & Total \\
\hline $\begin{array}{l}\text { Região 01 - Humaitá- } \\
\text { Navegantes }\end{array}$ & 729 & 818 & 1.247 & 1.089 & 1.683 & 458 & 6.024 \\
\hline Região 02 - Noroeste & 476 & 273 & 301 & 308 & 326 & 150 & 1.834 \\
\hline Região 03 - Leste & 358 & 469 & 780 & 865 & 654 & 564 & 3.690 \\
\hline Região 04 - Lomba do Pinheiro & 341 & 5 & 853 & 976 & 1.264 & 536 & 3.975 \\
\hline Região 05 - Norte & 304 & 917 & 769 & 837 & 459 & 501 & 3.787 \\
\hline Região 06 - Nordeste & 804 & 687 & 774 & 962 & 1.201 & 708 & 5.136 \\
\hline Região 07 - Partenon & 975 & 951 & 1.091 & 1.276 & 1.043 & 296 & 5.632 \\
\hline Região 08 - Restinga & 613 & 1.683 & 1.064 & 1.484 & 1.946 & 1.369 & 8.159 \\
\hline Região 09- Glória & 546 & 703 & 698 & 618 & 707 & 342 & 3.614 \\
\hline Região 10 - Cruzeiro & 166 & 338 & 336 & 351 & 280 & 231 & 1.702 \\
\hline Região 11 - Cristal & 213 & 301 & 307 & 200 & 336 & 394 & 1.751 \\
\hline Região 12 - Centro-Sul & 910 & 793 & 907 & 610 & 638 & 477 & 4.335 \\
\hline Região 13 - Extremo Sul & 504 & 74 & 788 & 1.443 & 1.038 & 558 & 4.405 \\
\hline Região 14 - Eixo Baltazar & 371 & 871 & 822 & 831 & 1.974 & 1.017 & 5.886 \\
\hline Região 15 - Sul & 506 & 667 & 1.112 & 1.135 & 948 & 597 & 4.965 \\
\hline Região 16 - Centro & 1.211 & 610 & 912 & 953 & 1.541 & 475 & 5.702 \\
\hline Região 17 - Ilhas & 227 & 210 & 335 & 248 & 316 & 244 & 1.580 \\
\hline Total & $\mathbf{9 . 2 5 4}$ & $\mathbf{1 0 . 3 7 0}$ & $\mathbf{1 3 . 0 9 6}$ & $\mathbf{1 4 . 1 8 6}$ & $\mathbf{1 6 . 3 5 4}$ & $\mathbf{8 . 9 1 7}$ & $\mathbf{7 2 . 1 7 7}$ \\
\hline
\end{tabular}

Fonte: Elaboração própria, a partir de dados disponibilizados pelo Município (PORTO ALEGRE, 2018).

Entre 2011 e 2015, verifica-se um crescimento contínuo da participação popular nas Assembleias temáticas do Orçamento Participativo a cada ano, e que passou de 9.256 votantes para 16.254, um aumento da ordem de aproximadamente 77\%. De 2015 para 2016, ao contrário, 
nota-se um decréscimo considerável da ordem de 54\%, quando apenas 8.917 pessoas votaram neste último ano. Tal decréscimo coincide com o momento culminante da crise de representatividade política por que passa o país, consistente no processo de Impeachment da presidenta da República.

Nem mesmo a variável política, relativa ao gestor que esteve à frente das discussões relativas ao Orçamento Participativo no período analisado pode ser considerado como motivo determinante para a diminuição da participação em 2016. De fato, durante todo o período analisado esteve à frente do Executivo municipal um mesmo mandatário, filiado ao PDT, o prefeito José Alberto Reus Fortunati, o que fortalece a hipótese da crise de representatividade por que passa o país.

Tabela 2 - Prefeitos e partidos entre - 2009 a 2018

\begin{tabular}{|l|c|c|c}
\hline \multirow{2}{*}{ Prefeitos } & \multirow{3}{c}{ Mandatos } \\
\cline { 3 - 4 } & Partido & Inicio & Fim \\
\hline José Alberto Reus Fortunati & PDT & $30 / 03 / 2010$ & $31 / 12 / 2012$ \\
\hline José Alberto Reus Fortunati & PDT & $01 / 01 / 2013$ & $31 / 12 / 2016$ \\
\hline
\end{tabular}

Fonte: Elaboração própria, a partir de dados disponibilizados pelo TRE, 2018.

Outra perspectiva importante diz respeito à representatividade do número de votantes no universo da população estimada do Município $^{7}$. Neste sentido, constata-se uma participação da ordem de $1,16 \%$ da população de Porto Alegre, quando se considera o ano de 2015, aquele no qual houve o maior o número de votantes. Esta constatação indica um amplo espaço a ser preenchido no processo de participação social e de consolidação de práticas democráticas.

Outra perspectiva interessante de análise é aquela que estratifica a participação segundo a faixa etária dos indivíduos, conforme indicado na Tabela 3:

Tabela 3 - Participação nas assembleias temáticas e regionais, segundo a faixa etária do participante - 2011 a 2016

\begin{tabular}{c|c|c|c|c|c|c}
\hline Idade / ano & $\mathbf{2 0 1 1}$ & $\mathbf{2 0 1 2}$ & $\mathbf{2 0 1 3}$ & $\mathbf{2 0 1 4}$ & $\mathbf{2 0 1 5}$ & $\mathbf{2 0 1 6}$ \\
\hline Até 30 anos & 2.792 & 3058 & 4163 & 4481 & 5111 & 2794 \\
\hline 31 à 45 & 3.834 & 3892 & 4761 & 5175 & 6295 & 3467 \\
\hline 46 à 59 & 3.367 & 4035 & 5225 & 5131 & 6033 & 3114 \\
\hline 60 á 75 & 1.516 & 1805 & 2178 & 2570 & 2961 & 1829 \\
\hline
\end{tabular}

7 Em 2010, a população de Porto Alegre foi estimada em 1.409.351 pessoas, https://cidades.ibge.gov.br/brasil/rs/porto-alegre/panorama. Acesso em 30 set. 2019. 


\begin{tabular}{c|c|c|c|c|c|c}
\hline $\begin{array}{c}\text { Acima de } 75 \\
\text { anos }\end{array}$ & 138 & 160 & 167 & 221 & 261 & 172 \\
\hline Total geral & 11.647 & 12.950 & 16.494 & 17.578 & 20.661 & 11.376 \\
\hline
\end{tabular}

Fonte: Elaboração própria, a partir de dados disponibilizados pelo Município (PORTO ALEGRE, 2018).

Em todo o período, há uma constante no que se refere à distribuição do número de votantes por faixa etária. A maior participação ocorre sempre entre a faixa dos 31 aos 45 e é seguida de perto pela faixa dos 46 aos 59 anos. A parcela mais jovem população, até 30 anos, é a terceira a contar com maior número de votantes. Considerando a pirâmide etária do município $^{8}$, percebe-se um ligeiro descompasso, na medida que esta última faixa, especialmente a parcela que vai dos 25 aos 29 anos, constitui o maior universo populacional do município em termos relativos.

A distribuição do número de participantes nas assembleias, regionais e temáticas segundo o gênero do participante é indicado na Tabela 4:

Tabela 4 - Distribuição nas assembleias temáticas e regionais segundo o gênero do participante - 2011 a 2016

\begin{tabular}{c|c|c|c}
\hline Ano/Sexo & Masculino & Feminino & Total \\
\hline 2011 & 4.856 & 6.791 & 11.647 \\
\hline 2012 & 5033 & 7917 & 12.950 \\
\hline 2013 & 7038 & 9456 & 16.494 \\
\hline 2014 & 7168 & 10410 & 17.578 \\
\hline 2015 & 8750 & 11911 & 20.661 \\
\hline 2016 & 4656 & 6720 & 11.376 \\
\hline Total Geral & $\mathbf{3 7 . 5 0 1}$ & $\mathbf{5 3 . 2 0 5}$ & $\mathbf{9 0 . 7 0 6}$
\end{tabular}

Fonte: Elaboração própria, a partir de dados disponibilizados pelo Município (PORTO ALEGRE, 2018).

A participação das mulheres é sempre superior à dos homens em todo o período considerado. Tendo em vista o número total de participantes, as mulheres representaram o equivalente a 58,6\%. Tal percentual é superior inclusive à composição do gênero feminino no número total de habitantes do município. Neste último caso, as mulheres representam $53,5 \%$ da população de Porto Alegre, o que demonstra uma maior inclinação das participantes nas discussões sobre Orçamento Participativo.

\footnotetext{
${ }^{8}$ Vid. https://cidades.ibge.gov.br/brasil/rs/porto-alegre/panorama. Acesso em 30 set. 2019.
} 


\section{LIMITES E OPORTUNIDADES OFERECIDAS PELO ORÇAMENTO PARTICIPATIVO}

A experiência do Orçamento Participativo de Porto Alegre originou-se graças a uma sociedade civil atuante e foi liderada por forças políticas de esquerda. Tornou-se um instrumento-modelo no âmbito de uma gestão pública participativa em diversos municípios brasileiros, e ganhou destaque nacional e internacional a partir de 1989. A partir de "manifestações sociais por pluralismo político, socialização dos recursos públicos, direitos de cidadania", terminou por contribuir na formação "de uma nova gramática social e uma nova forma de relação entre Estado e sociedade" (AVRITZER, 2002, p. 54).

Não obstante, existem limites à sua efetivação. Um deles decorre da própria escassez de recursos, própria da condução das decisões no âmbito da Economia. O não atendimento de todas as reivindicações da população, termina por acarretar conflitos e dificuldades de negociação. Trata-se, entretanto, de uma limitação apenas aparente, na medida em que deve ser visto como parte do processo de aprendizagem sobre como lidar com a escassez de recursos e a natureza das deliberações coletivas. É neste sentido que Sanchez (2002) considera que o Orçamento Participativo se trata do momento mais importante no exercício da democracia, devido ao embate que ele fomenta entre o poder público e a sociedade civil.

No mesmo sentido, deve-se considerar também que as decisões adotadas no âmbito da formulação de um Orçamento Público, podem não ser efetivadas. Isto decorre da própria natureza de qualquer que seja o orçamento. Como esclarece Gohn (2001, p. 91), "o fato das decisões dos conselhos terem caráter deliberativo, não garante que as decisões se efetivem, pois não há estruturas jurídicas que deem amparo legal e obriguem o executivo a acatá-las”. De fato, o Orçamento Público não tem caráter impositivo, servindo como instrumento de planejamento financeiro do Estado.

Assim, por meio da adoção do Orçamento Participativo, o município assume um papel relevante na própria formação da consciência política da sociedade, que transcende o caráter participativo, e passa para o plano do conhecimento técnico sobre a sistemática das finanças públicas e repartição de recursos e da riqueza produzida pela coletividade.

É a este aspecto pedagógico que Carlos (2015, p. 34) chama a atenção. Segundo ele, a 
técnica e política que possibilitasse a formulação de propostas políticas mais definidas, com vistas à participação institucional em assuntos relacionados a políticas públicas.

Em seu caráter educativo, “a participação pode aumentar o valor da liberdade para o indivíduo, capacitando-o a ser seu próprio senhor" (PATEMAN, 1992, p.40).

O Orçamento Participativo teve seu início de implantação em Porto Alegre, onde, historicamente, as associações de moradores são as que mais frequentam as reuniões. Os participantes, vinculados a tais associações, representam 48,9\% do público, seguidos de membros de movimentos sociais, que representam 13,5\%, do mesmo universo, e das entidades assistenciais, cujos associados representam 9,2\%, dos presentes nas reuniões. No que se refere às entidades assistenciais, o aumento da sua participação se deu devido à municipalização de políticas públicas, quando houve um aumento expressivo de convênios entre a Prefeitura e as entidades civis (FEDOZZI, 2007).

Também se tem notado um aumento da participação de pessoas não vinculadas a nenhum tipo de representação. Entretanto, é importante notar que a condição de membro de uma coletividade, e especialmente a condição de liderança nesta coletividade, termina por repercutir na capacidade de assumir posições de destaque nas estruturas deliberativas do Orçamento Participativa. Em uma pesquisa realizada em 2009 verificou-se que

Enquanto os eleitos estão relacionados à condição de participantes em entidades ou movimentos sociais, os não eleitos estão associados à inexistência desse tipo de vínculo. Por isso, dentre os eleitos conselheiros e delegados, o percentual de pertencimento a formas associativas é comparativamente elevado $(92,6 \%$ dos conselheiros e $80,4 \%$ dos delegados) aos demais não eleitos $(51,2 \%)$. Ou seja, a condição de liderança é fator decisivo tanto para galgar funções representativas nas instâncias de poder do OP, como para a maior permanência no mesmo: 87,8\% reafirmou sua condição de liderança comunitária para justificar a presença anterior nas edições do OP (FEDOZZI, 2013, p. 97).

Também no que se refere à preferência partidária manifestada pelos participantes, notase que a maior parte daqueles que ocupam espaço nas estruturas deliberativas do Orçamento Participativo demonstram simpatias partidárias. Segundo Cesar (2012), 49,7\% dos entrevistados manifestam tal preferência, contra 33,9\%. "Além disso, dentre os representantes eleitos para o OP, os percentuais de simpatia partidária são crescentes, compõem 58,0\% dos delegados e 68,5\% dos conselheiros" (FEDOZZI, FURTADO, DOZOLINA, BASSANI, MACEDO, PARENZA, CRUZ, 2013, p. 100) 
Há ainda que se notar a possibilidade de que os participantes façam parte de coletivos não-formais, de caráter momentâneo. De fato, este é um novo modelo de grupo político, trazido sobretudo por meio das novas tecnologias da informação e que não pode ser desprezado. Tratase de produto de uma transformação na forma de mobilização para as assembleias, que se faz por meio de redes informais, menos orgânicas e mais momentâneas, que podem ser convocadas de forma pontual, tanto no que se refere ao tema a ser discutido, como da sua duração.

O perfil socioeconômico também é uma variável importante para avaliar a composição do Orçamento Participativo. Nesta linha, um aspecto muito interessante foi identificado pela prefeitura de Porto Alegre (PORTO ALEGRE, 2006), no que se refere ao grau de formação dos indivíduos. Segundo o levantamento realizado, o grupo de participantes com nível de ensino fundamental é menos presente em termos comparativos, e quando está presente encontra-se associado a temas ligados a motivações concretas e imediatas. Por outro lado, os grupos de participantes que têm ensino médio tendem a estabelecer uma relação de conhecimento e controle das estruturas do Orçamento Participativo. Finalmente, os participantes com ensino superior tendem a estar movidos por uma questão de identidade e de solidariedade comunitária, de exercício democrático e de efetividade de direitos de cidadania.

\section{CONCLUSÕES}

A experiência do Orçamento Participativo de Porto Alegre tornou-se uma referência em todo mundo, não apenas no seu aspecto técnico ou operacional, mas sobretudo enquanto instrumento viabilizador do exercício da cidadania, e efetividade da participação democrática. Muito além da questão pedagógica referente aos trâmites para formulação de uma proposta orçamentária, o Orçamento Participativo viabiliza a identificação do indivíduo enquanto agente responsável pela condução da coisa pública, e transformador da realidade social.

Não é por acaso que a grande maioria dos estudos teóricos e empíricos, produzidos sobre as experiências de orçamento participativo, têm privilegiado a análise, acerca da complexidade das relações políticas e sociais, desencadeadas com a criação dos novos canais de participação social. A implantação do Orçamento Participativo, como fato isolado, não garante o fortalecimento da sociedade civil. De qualquer maneira, para a maioria dos participantes, a avaliação é de que, após a criação desse modelo participativo o movimento comunitário e popular da cidade termina por restar fortalecido. 
O Orçamento Participativo contém, em seu contexto, a democracia participativa, simultaneamente um conjunto de objetivos, que evidenciam a realidade de Porto Alegre; a presença do alicerce social, das classes populares, com importante grau de ação na esfera pública, que foi decisiva para a qualidade do processo. Assim, a análise geral sobre este instrumento de gestão é positiva nas dimensões políticas, sociais e culturais da cidadania.

O Programa de Orçamento Participativo conta com apoio internacional, a exemplo do apoio concedido pelo Banco Mundial, que vem estimulando, ademais, a sua continuidade.

A diminuição da participação da população no ano de 2016 deve ser entendida como reflexo da crise de representatividade por que passa o país e o mundo, e que termina por fragilizar toda a estrutura de participação popular e democrática. É exatamente neste contexto que iniciativas que fomentem a participação, a exemplo do Orçamento Participativo, devem ser ainda mais estimuladas.

É importante compreender o contexto histórico em que foi concebido o Orçamento Participativo, a sua importância política e social, bem como a sua estrutura e dinâmica de funcionamento, tudo com vistas a promover a intensificação da sua utilização e aperfeiçoamento das suas bases.

Também é importante estar atento às críticas que sofre, seja para protege-lo de interesses que têm como objetivo desacreditá-lo, seja para incorporar aquelas observações que de fato apontam para fragilidade, com vistas a melhorá-lo. São comuns as críticas no sentido de que Orçamento Participativo seria operacionalizado por interesses partidários, principalmente em anos de eleições. Sobre isto, é necessário compreender que o Orçamento Participativo pode servir de palco para a realização dos grandes debates públicos, de forma legítima e aberta, a bem do próprio amadurecimento da participação cidadão, da inclusão social e do exercício da democracia.

O Orçamento Participativo implementado a partir de Porto Alegre é sem dúvida símbolo de um avanço democrático, de envolvimento político direto da população no quotidiano da administração pública, o que possibilita que uma grande parcela de indivíduos se aproprie da responsabilidade de enfrentamento das questões que dizem respeito ao próprio desenvolvimento da comunidade. 


\section{REFERÊNCIAS}

ATLAS BRASIL, ATLAS DO DESENVOLVIMENTO HUMANO NO BRASIL. Índice de Desenvolvimento Humano Municipal (IDHM). 2010. Disponível em: <Disponível em: http://www.atlasbrasil.org.br/2013/pt/perfil_m/porto-alegre_rs\#idh. Acesso em: 25 jun. 2018.> Acesso em: 22 jun. 2018.

AVRITZER, Leonardo. "Modelos de deliberação democrática: uma análise do orçamento participativo no Brasil”. In: SANTOS, Boaventura de Souza. (Org.). Democratizar a democracia participativa: os caminhos da democracia participativa. Rio de Janeiro: Civilização Brasileira, 2002. p. 561-597.

BANCO MUNDIAL Washington DC. Governance and development. 1992. Disponível em: http://www.gsid.nagoya-u.ac.jp/sotsubo/Governance_and_Development_1992.pdf. Acesso em: 7 set. 2019.

BOBBIO, Norberto. Teoria geral da política. Rio de Janeiro/RJ: Campus, 2000.

BRANDÃO, Carlos. Território e desenvolvimento: as múltiplas escalas entre o local e o global. Campinas/SP: Unicamp, 2014.

BRANDÃO, Elias Canuto. Avanços, limites e desafios da participação popular no Orçamento Participativo: o estudo do caso do OP de Maringuá/PR. Tese (Doutorado em Sociologia), Araraquara, 2005.

BRASIL. Governo Federal. Casa Civil. Constituição da República Federativa do Brasil. 48ed. Brasília/DF: Câmara dos Deputados, 2015.

BRASIL. Governo Federal. Ministério da Economia, Planejamento Desenvolvimento e Gestão, 2015. O que é orçamento participativo? Disponível em:

$<$ http://www.planejamento.gov.br/servicos/faq/orcamento-da-uniao/elaboracao-e-execucaodo-orcamento/o-que-e-orcamento-participativo>. Acessado em: 20. out. 2019.

BUSATTO, César. Governança solidária e estado mínimo. Porto Alegre/RS: PMPA, 2005. Disponível em:

$<$ http://lproweb.procempa.com.br/pmpa/prefpoa/observatorio/usu_doc/governanca_solidaria_ e_estado_minimo.pdf >. Acesso em: 10 jun. 2018.

CABANNES, Yves. Los presupuestos participativos: una contribución a la gobernanza urbana y a los objetivos de desarrollo del milenio. Campaña Mundial Sobre Gobernanza Urbana. ONU, 2004. Disponível em:

<http://base.socioeco.org/docs/documento_conceptual_es_presupuesto_participativo.pdf >. Acesso em: 7 set. 2019.

CARLOS Euzeneia. Controle social e política redistributiva no orçamento participativo Vitória/ES: EDUFES, 2015. 
Controle social e política redistributiva: as experiências de orçamento participativo em Vitória e Serra/ES. 2003, 207p. Dissertação (Mestrado), Instituto de Pesquisa e Planejamento Urbano e Regional/IPPUR - Universidade Federal do Rio de Janeiro, Rio de Janeiro, 2003.

CARRION, Eduardo Kroeff Machado. A respeito da democracia participativa. In: GRAU, Eros Roberto; GUERRA FILHO, Willis Santiago. Estudos de direito constitucional: homenagem a Paulo Bonavides. São Paulo/SP: LTR, 2001.

CESAR, Benedito Tadeu. A especificidade política de Porto Alegre. Jornal Sul 21, Porto Alegre/RS, 2012. Disponível em: <http://www.sul21.com.br/jornal/>. Acesso em: 22 jun.2018.

FEDOZZI, Luciano. Observando o orçamento participativo de Porto Alegre, análise histórica de dados: perfil social e associativo, avaliação e expectativas. Porto Alegre/RS: Tomo, 2007.

Orçamento participativo: reflexões sobre a experiência de Porto Alegre. 3.ed. Porto Alegre/RS: IPPIR, 2001.

Orçamento Participativo de Porto Alegre Gênese, avanços a limites de uma idéia que se globaliza. Cidades, Comunidades e Territórios, n.0 18, 2009, pp. 41 -57.

FEDOZZI, Luciano; FURTADO Adriana; BASSANI, Valéria Dozolina Sartori, MACEDO, Carlos Eduardo Gomes, PARENZA, Cidriana Teresa; CRUZ, Milton. Orçamento participativo de Porto Alegre: perfil, avaliação e percepções do público participante. Porto Alegre/RS: Hartmann, 2013, p. 97. Disponível em:

<http://lproweb.procempa.com.br/pmpa/prefpoa/observatorio/usu_doc/livro_op.pdf >. Acesso em: 7 set. 2019.

FERRAREZI, Elisabete; OLIVEIRA Mariana S. Carvalho. Conferências nacionais de saúde e processos participativos na administração pública federal brasileira. Brasília/DF: Casoteca; ENAP; 2010.

GENRO, Tarso; SOUZA, Ubiratan de. Orçamento participativo: a experiência de Porto Alegre. 4ed. São Paulo/SP: Fundação Perseu Abramo, 2002.

GOHN, Maria da Glória. Participação: novas e antigas concepções na gestão pública. ENCONTRO DA ANPUR, 9, Anais, Rio de Janeiro/RJ, 2001, p. 1206-1217.

Orçamento público e participação popular. Fórum Nacional de Participação

Popular nas Administrações Municipais: balanço das experiências de orçamento participativo nos governos locais. Brasília/DF: Polis, n. 4, 1999, p. 23-34.

GOMES, João Salis. A avaliação de políticas públicas e a governabilidade. In: MOZZICAFREDDO, Juan; GOMES, João Salis; BATISTA, João S. (Orgs.), Ética e administração: como modernizar os serviços públicos? Oeiras/PI: Celta, 2003.

GOYARD-FABRE, Simone. O que é democracia. São Paulo/SP: Martins Fontes, 2003. 
IBGE, Fundação Instituto Brasileiro de Geografia e Estatística. População. Cidades 2017. Disponível em: < https://cidades.ibge.gov.br/brasil/rs/porto-alegre/panorama>. Acesso em: 4 jun. 2018.

. Pirâmide Etária 2010. Disponível em:

<https://cidades.ibge.gov.br/brasil/rs/porto-alegre/panorama>. Acesso em 30 set. 2019.

Trabalho e rendimento e economia. 2015. Disponível em: <

https://cidades.ibge.gov.br/brasil/rs/porto-alegre/panorama>. Acesso em: 4 jun. 2018.

Enciclopédia dos municípios brasileiros. 1959. Disponível em: <https: https://biblioteca.ibge.gov.br/visualizacao/livros/liv27295_34.pdf >. Acesso em: 3 set. 2019.

Enciclopédia dos Municípios Brasileiros. 1958. Disponível em: < https://biblioteca.ibge.gov.br/visualizacao/livros/liv27295_35.pdf>. Acesso em: 4 jun. 2018.

Brasil; enciclopédias e dicionários; municípios. 1957-1964. Disponível em: $<$ https://biblioteca.ibge.gov.br/index.php/biblioteca-atalogo?view=detalhes\&id=227295>. Acesso em: 4 jun. 2018.

KHAIR, Almir Antônio. Gestão fiscal responsável: guia de orientação para as prefeituras. Porto Alegre/RS: Conselho Regional de Contabilidade do Rio Grande do Sul, 2001.

DI PIETRO, Maria Sylvia Zanella. Participação da comunidade em órgãos da Administração Pública. Revista de Direito Sanitário, vol. I, n. 1, novembro de 2000. p. 39.

MATIAS-PEREIRA, José. Governança no setor público. São Paulo: Atlas, 2010.

MILANI, Carlos; SOLINÍS, Germán. Pensar a democracia na governança mundial: algumas pistas para o futuro. In: MILANI, Carlos; ARTURI, Carlos; SOLÍNÍS, Germán. Democracia e governança mundial: que regulações para o século XXI? Porto Alegre/RS: UFRGS, 2002.

MORONI, José Antônio. O direito à participação no governo Lula. In. FLEURY, Sônia;

LOBATO, Lenaura de Vasconcelos Costa Lobato. (orgs.). Participação, Democracia e saúde. Rio de Janeiro: CEBES, 2009. p. 248-269.

NAVARRO, Zander. O orçamento participativo de Porto Alegre (1989-2002): um conciso comentário crítico. In: AVRITZER, Leonardo; NAVARRO, Zander (Orgs.). A inovação democrática no Brasil. São Paulo/SP: Cortez, 2003. p. 89-128.

OLIVEIRA, Osmany Porto de. Embaixadores da participação: a difusão internacional do orçamento participativo. São Paulo/SP: Annablume, 2016.

PAIVA, Maria Arair Pinto (Org.). Direito: controle e autonomia no espaço público. Rio de Janeiro/RJ: Uapê, 2006.

PATEMAN, Carole. Participação e teoria democrática. São Paulo/SP: Paz e Terra, 1992. 
PEREZ, Marcos Augusto. A administração pública democrática: institutos de participação popular na administração pública. Belo Horizonte/BH: Fórum, 2009.

PIRES, Valdemir. Orçamento participativo: o que é, para que serve, como se faz. São Paulo/SP: Manole, 2001.

PORTO ALEGRE. Prefeitura Municipal de Porto Alegre. Governança solidária local: a experiência de Porto Alegre. Apresentação de slides. Disponível em:

$<$ http://lproweb.procempa.com.br/pmpa/prefpoa/smgl/usu_doc/o_que_e_governanca_junho_2 006.pdd>. Acesso em: 6 jun. 2018.

Governança solidária local: Modelo de gestão 2014. Disponível em:

<http://lproweb.procempa.com.br/pmpa/prefpoa/smpeo/usu_doc/manual_de_gestao_prefeitur a_2014_site.pdf $>$. Acesso em: 8 set. 2019.

. Modelo de gestão: movimento Brasil competitivo, programa gaúcho da qualidade e produtividade. 2014 Disponível em: < http://lproweb.procempa.com.br/pmpa/prefpoa/smpeo/usu_doc/manual_de_gestao_prefeitura _2014_site.pdf >. Acesso em: 3 jun. 2018.

. Prioridades eleitas OP 2016-2017. Disponível em:

<http://www2.portoalegre.rs.gov.br/op/default.php?p_secao=106>. Acesso em: 24 jun. 2018.

. Termos que compõe a linguagem do orçamento participativo. 2018.

<Disponível em: http://www2.portoalegre.rs.gov.br/op/default.php?p_secao=18>. Acesso em: 24 jun. 2018.

. Termos que compõe a linguagem do orçamento participativo. 2018.

<Disponível em: http://www2.portoalegre.rs.gov.br/op/default.php?p_secao=18>. Acesso em: 24 jun. 2018.

. Histórico da Cidade. 2018. Disponível em:

<http://www2.portoalegre.rs.gov.br/turismo/default.php?p_secao=257>. Acesso em: 24 jun. 2018.

SÁNCHEZ, Félix. Orçamento participativo: teoria e prática. São Paulo/SP: Cortez, 2002.

SANTOS, Boaventura de Sousa, Pela mão de Alice: o social e o político na pós-modernidade. São Paulo, Cortez, 1995, p. 54.

SINTOMER, Yves; HERZBERG, Carsten; RÖCKE, Anja. Modelos transacionais de participação cidadã: o caso do orçamento participativo. Sociologias, Porto Alegre. v. 14, n . 30, mai./ago. p. 80, 2012.

VAINER, Carlos Bernardo. As escalas do poder e o poder das escalas: o que pode o poder local? Encontro da ANPUR, 9, Anais, Rio de Janeiro/RJ: ANPUR, 2001, p. 140-151.

VIGLIO, José Eduardo. Avaliação da experiência do orçamento participativo numa cidade média: o caso de Jaboticabal/SP. 2004. 173p. Dissertação (Mestrado), Programa em 
Quaestio Iuris

Engenharia Urbana, Centro de Ciências Exatas e de Tecnologia - Universidade Federal de São Carlos, São Carlos/SP, 2004.

Trabalho recebido em 23 de novembro de 2019

Aceito em 05 de dezembro de 2020 